\title{
METABOLISM OF INTRAVENOUS FRUCTOSE AND GLUCOSE IN NORMAL AND DIABETIC SUBJECTS ${ }^{1,2}$
}

\author{
By MAX MILLER, WILLIAM R. DRUCKER, J. E. OWENS, JAMES W. CRAIG, AND \\ HIRAM WOODWARD, JR.
}

\begin{abstract}
(From the Department of Medicine, Western Reserve University School of Medicine, Cleveland, Ohio)
\end{abstract}

(Submitted for publication September 10, 1951; accepted October 22, 1951)

Although fructose metabolism has been studied extensively in various animal species, no careful investigation has been made of the utilization and metabolic effects of intravenously administered fructose in humans with diabetes mellitus. It has long been recognized from animal studies that the metabolism of fructose differed significantly from that of glucose, despite the close similarity in chemical structure. This led to a trial of its utilization orally in patients with diabetes $(1,2)$. At first the fructose seemed to be well-utilized, but glycosuria increased gradually until the fructose balance became similar to that obtained with comparable amounts of glucose. In 1946 Root, Stotz and Carpenter (3) found that $50 \mathrm{gm}$. of fructose given orally to diabetic subjects produced greater rises in $R Q$, blood pyruvate and lactate than the same amount of glucose. Root concluded that "the intermediary metabolism of fructose is, with diabetic patients, as with normal subjects, different from that of glucose." Oral administration, however, cannot be expected to demonstrate quantitatively the effects of fructose, since both intestinal mucosa and liver would convert at least a portion to glucose $(4,5)$ as a consequence of the presence of both hexose isomerase and phosphatase. In the one mild diabetic patient in the series of Weichselbaum, Elman and Lund (6) where the tolerance to intravenous fructose was studied, the blood levels and urinary excretion of fructose seemed to be in the same range as those found in non-diabetic subjects.

Bueding, Wortis and Fein (7) showed that in the diabetic subject, in the absence of insulin, the administration of glucose orally was not accom-

1 Presented to the Society for Experimental Biology and Medicine, Cleveland Section, May 11, 1951, and to the Central Society for Clinical Research, Chicago, November 2, 1951.

2 This work was supported in part by a grant from the Cleveland Diabetic Fund. panied by the same rise in blood pyruvate found in the normal subject under identical experimental conditions. With the injection of insulin in the diabetic subject a rise in pyruvate occurred. This seemed to indicate the possibility that insulin might act on one or more of the reactions in the EmbdenMeyerhof scheme between glucose and pyruvate. In 1945 Price, Cori and Colowick (8) demonstrated in vitro that insulin diminished or abolished the inhibitory action of the anterior pituitary hormone on the enzyme, hexokinase, which catalyzes the phosphorylation of glucose. Some doubt has been raised as to the physiological significance of this action in view of the increased sensitivity to insulin of the hypophysectomized animal and the patient with destruction or degeneration of the pituitary gland (Simmond's disease). The need for further work concerning the nature of the metabolic defect in human diabetes is still apparent. Study of the intermediary metabolism of fructose, entering the Embden-Meyerhof scheme as it does at a point other than the glucose phosphorylation step, would help to resolve some of these controversial issues.

\section{EXPERIMENTAL PROCEDURES AND METHODS}

Fructose ${ }^{3}$ and glucose in amounts of $1.0 \mathrm{gm}$. per $\mathrm{kg}$. were administered intravenously in a $10 \%$ solution during a period of 60 minutes to three normal adult males and five patients with diabetes mellitus. The diabetes was severe enough in all instances to require insulin. Regular insulin was given in two doses, one before breakfast and one before supper for three days, in order that, on the morning of any test, when insulin was withheld, the last dose of insulin would have been received at least 14 hours before and no significant insulin effect would be present. Fasting hyperglycemia of over $200 \mathrm{mg}$. per $100 \mathrm{ml}$. was usually present, with concomitant glycosuria. None of the subjects had any clinical signs of thiamine

3 The fructose for intravenous use was generously supplied by Dr. Warren Cox, Jr., Medical Director of Mead Johnson \& Company. 
deficiency, but B complex capsules were given for three days prior to the tests so that the supplementary thiamine intake was at least $20 \mathrm{mg}$. daily. This was done to eliminate any possible effect of a subclinical thiamine deficiency on pyruvate metabolism. The previous diets were all nutritionally adequate by present-day dietary standards, and for the diabetic subjects averaged $180 \mathrm{gm}$. of carbohydrate daily. The tests were done in the post-absorptive state (overnight fast) and in the resting state (to avoid the rise in pyruvic acid after muscular exertion).

The fructose and glucose were given to the patients usually on alternate days or after an interval of one day. Since each patient received both fructose and glucose on separate occasions, the effects of fructose could be compared directly with those of glucose in the same individual. In addition, the effects in the diabetic subject could be compared with those in the non-diabetic control. Samples of peripheral venous blood were drawn before the start of the 60-minute infusion and one-half, one, one and one-half, two, and three hours after the start of the infusion. Urine samples were collected before and at intervals up to three hours during the experiment. The blood samples were analyzed for glucose, fructose, pyruvic acid, citric acid, and inorganic phosphorus; the urine samples were analyzed for glucose and fructose. The following determinations were used as indicators of intermediary metabolism and utilization of the hexose: changes in blood pyruvic acid, plasma citric acid, and serum inorganic phosphorus; the disappearance of hexose from the blood stream; and the net amount of hexose retained in the body, obtained by subtracting the number of grams excreted in the urine from the total amount given.

Blood glucose was determined by the method of Somogyi (9) ; blood fructose, by the method of Roe as modified by Higashi and L. Peters (10). There was no interference with the fructose determination by blood glucose levels up to $300 \mathrm{mg}$. per $100 \mathrm{ml}$. A blood glucose level of $450 \mathrm{mg}$. per $100 \mathrm{ml}$. caused an increase in the blood fructose measurement of $6 \mathrm{mg}$. per $100 \mathrm{ml}$, and a blood glucose level of $900 \mathrm{mg}$. per $100 \mathrm{ml}$. resulted in a corresponding rise of $12 \mathrm{mg}$. per $100 \mathrm{ml}$. Appropriate corrections were made on the above basis. The blood pyruvic acid was determined by the method of Friedemann and Haugen (11). Plasma citric acid was done by a combination of methods of Natelson, Pincus and Lugovoy (12) and of Taussky and Shorr (13). The Fiske and Subbarow method (14) was used for serum inorganic phosphorus.

The significance of changes in blood glucose, blood pyruvic acid, and plasma citric acid was estimated from the results of the following experiment. Blood samples from each of four normal subjects were drawn at 30 to 60 minute intervals for three and one-half hours under the same experimental conditions outlined above, except that no infusion was given. Using the initial level as a reference the mean standard deviations $(\sigma)$ and their variances, in mg. per $100 \mathrm{ml}$., were as follows: for glucose, $\sigma=3.0 \pm 1.4 ;$ for pyruvic acid, $0.17 \pm 0.037$; and for citric acid, $0.15 \pm 0.096$.

\section{RESULTS}

A. Normal subjects. The complete data depicting the metabolic effects of intravenous glucose and fructose are shown in Tables I and II. After glucose the average rise in blood glucose above the initial level was $176 \mathrm{mg}$. per $100 \mathrm{ml}$., followed by a rapid fall to hypoglycemic levels 60 minutes after the infusion was completed, with a subsequent return to normal. After fructose, however, the average rise in blood fructose above the initial level was $81 \mathrm{mg}$. per $100 \mathrm{ml}$., which was less than one-half that obtained with glucose given in comparable amounts and at the same rate. A rise in blood glucose following fructose administration was noted in two of the three cases.

The excretion of fructose in the urine during the three hour period of the experiment was in the same range as that of glucose. On the average somewhat less than $10 \%$ of the administered fructose or glucose appeared in the urine. No threshold for fructose excretion was found, since significant fructosuria was present even at blood levels as low as $4 \mathrm{mg}$. per $100 \mathrm{ml}$.

Pyruvic acid levels rose on the average $32 \%$ or $0.31 \mathrm{mg}$. per $100 \mathrm{ml}$. above the control level after glucose; ${ }^{4}$ but the rise after fructose was three times as great. Citric acid levels after glucose $^{4}$ fell slightly in the two cases studied; but after fructose citric acid rose in all three cases.

Serum inorganic phosphorus fell invariably after fructose administration in normal subjects. Serum phosphorus was not measured after glucose, since the drop in inorganic phosphorus has been so well established by others. ${ }^{5}$

The administration of fructose to a fourth nondiabetic subject produced similar changes: rises in pyruvic acid (2.09 mg. per $100 \mathrm{ml}$.), citric

4 In this laboratory a larger series of normal subjects comprising 10 individuals given $1 \mathrm{gm}$. of glucose per $\mathbf{~ k g . ~}$ intravenously in a period of 60 minutes showed an average maximal increase in pyruvic acid of $35.7 \%$ or $0.36 \mathrm{mg}$. per $100 \mathrm{ml}$. and an average fall of $20.5 \%$ or $0.43 \mathrm{mg}$. per $100 \mathrm{ml}$. in citric acid.

${ }^{5}$ Forsham and Thorn (16) found an average fall of $25 \%$ in the serum phosphorus of normal subjects after intravenous administration of $0.5 \mathbf{~ g m}$. of glucose per $\mathbf{~ k g}$. in 30 minutes. In one of our normal subjects (J. C.) the serum phosphorus fell $27 \%$ after $1 \mathrm{gm}$. of glucose per $\mathrm{kg}$. in 60 minutes given at a date subsequent to the experiment listed in Table I. 
TABLE I

Comparison of effects of intravenous glucose and fructose in normal subjects

( $1 \mathrm{gm}$. per $\mathrm{kg}$. as $10 \%$ solution in 60 minutes)

\begin{tabular}{|c|c|c|c|c|c|c|c|c|c|c|c|}
\hline \multirow[b]{2}{*}{ Subject } & \multicolumn{5}{|c|}{ Glucose } & \multicolumn{6}{|c|}{ Fructose } \\
\hline & Date & Time & $\begin{array}{c}\text { Blood } \\
\text { glucose }\end{array}$ & $\begin{array}{c}\text { Blood } \\
\text { pyruvic } \\
\text { acid }\end{array}$ & $\begin{array}{c}\text { Plasma } \\
\text { citric } \\
\text { acid }\end{array}$ & Date & $\begin{array}{c}\text { Blood } \\
\text { fructose }\end{array}$ & $\begin{array}{c}\text { Blood } \\
\text { pyruvic } \\
\text { acid }\end{array}$ & $\begin{array}{c}\text { Plasma } \\
\text { citric } \\
\text { acid }\end{array}$ & $\begin{array}{l}\text { Serum } \\
\text { inorg. } \\
\mathbf{P}\end{array}$ & $\underset{\text { glucose }}{\text { Bloce }}$ \\
\hline $\begin{array}{c}\text { J. O. } \\
\text { Age } \\
30 \\
\text { Wt. } \\
61 \mathrm{~kg} .\end{array}$ & $8 / 17 / 50$ & $\begin{array}{r}\min . \\
0 \\
30 \\
60 \\
90 \\
120 \\
150 \\
180\end{array}$ & $\begin{array}{c}\text { mg. } \% \\
78 \\
234 \\
263 \\
79 \\
42 \\
50\end{array}$ & $\begin{array}{c}\text { mg. \% } \\
1.20 \\
1.15 \\
1.36 \\
1.28 \\
1.15 \\
1.50^{*}\end{array}$ & mg. \% & $5 / 3 / 51$ & $\begin{array}{c}m g . \% \\
2 \\
58 \\
68 \\
26 \\
10 \\
5\end{array}$ & $\begin{array}{c}\text { mg. \% } \\
1.31 \\
2.81 \\
2.78 \\
1.71 \\
1.04 \\
1.07\end{array}$ & $\begin{array}{c}\text { mg. \% } \\
1.73 \\
2.12 \\
2.12 \\
2.24 \\
2.04 \\
\\
1.71\end{array}$ & $\begin{array}{c}\text { mg. } \% \\
3.28 \\
2.50 \\
2.48 \\
2.99 \\
2.96 \\
\\
2.93\end{array}$ & $\begin{array}{c}\text { mg. } \% \\
85 \\
88 \\
110 \\
84 \\
74 \\
76\end{array}$ \\
\hline $\begin{array}{c}\text { J. C. } \\
\text { Age } \\
30 \\
\text { Wt. } \\
67 \mathrm{~kg} .\end{array}$ & $9 / 5 / 50$ & $\begin{array}{r}0 \\
30 \\
60 \\
90 \\
120 \\
180\end{array}$ & $\begin{array}{r}74 \\
213 \\
202 \\
54 \\
39 \\
68\end{array}$ & $\begin{array}{l}0.80 \\
1.12 \\
1.23 \\
0.96 \\
0.88 \\
1.47^{*}\end{array}$ & $\begin{array}{l}2.08 \\
1.89 \\
1.99 \\
2.18 \\
2.08 \\
2.05\end{array}$ & $5 / 7 / 51$ & $\begin{array}{r}1 \\
90 \\
97 \\
27 \\
12 \\
5\end{array}$ & $\begin{array}{l}1.15 \\
1.95 \\
2.19 \\
1.68 \\
1.28 \\
0.88\end{array}$ & $\begin{array}{l}2.16 \\
2.12 \\
2.24 \\
2.48 \\
2.10 \\
1.86\end{array}$ & $\begin{array}{l}2.87 \\
1.77 \\
1.77 \\
2.82 \\
2.92 \\
3.20\end{array}$ & $\begin{array}{l}78 \\
90 \\
94 \\
61 \\
71 \\
81\end{array}$ \\
\hline $\begin{array}{c}\text { W. D. } \\
\text { Age } \\
28 \\
\text { Wt. } \\
80 \mathrm{~kg} .\end{array}$ & $9 / 28 / 50$ & $\begin{array}{r}0 \\
30 \\
60 \\
90 \\
120 \\
180 \\
240\end{array}$ & $\begin{array}{r}79 \\
\\
283 \\
98 \\
42 \\
71 \\
88\end{array}$ & $\begin{array}{l}1.20 \\
1.55 \\
1.31 \\
1.28 \\
1.28 \\
0.75\end{array}$ & $\begin{array}{l}2.86 \\
2.80 \\
2.68 \\
2.38 \\
2.58 \\
2.42\end{array}$ & $3 / 15 / 51$ & $\begin{array}{c}1 \\
144 \dagger \\
34 \\
14 \\
4 \\
1\end{array}$ & $\begin{array}{l}0.91 \\
\\
1.76 \\
1.63 \\
1.23 \\
0.96 \\
1.10\end{array}$ & $\begin{array}{l}2.18 \\
\\
2.30 \\
2.53 \\
2.47 \\
1.71 \\
1.38\end{array}$ & $\begin{array}{l}3.15 \\
1.80 \\
3.26 \\
3.04 \\
2.99 \\
2.99\end{array}$ & $\begin{array}{l}89 \\
\\
85 \\
85 \\
61 \\
71 \\
76\end{array}$ \\
\hline
\end{tabular}

* A second rise in pyruvic acid accompanying the hypoglycemia which follows intravenous glucose administration occurs in the majority of cases (15).

t Infusion stopped at 30 minutes; restarted and speeded up at end; hence very high value at 60 minutes. Value omitted from average.

acid ( $0.57 \mathrm{mg}$. per $100 \mathrm{ml}$.$) , and glucose (9 \mathrm{mg}$. per $100 \mathrm{ml}$.$) ; and a fall in serum inorganic$ phosphorus (0.37 mg. per $100 \mathrm{ml}$.). Two gm. of fructose were excreted in the three hour period. A glucose experiment was not performed in this subject, eliminating the opportunity for a direct comparison of the effects.

Figure 1 compares graphically the changes after glucose and fructose in a typical experiment (Subject J. C.).
B. Diabetes mellitus. The data obtained in five cases of diabetes mellitus have been listed in Tables III and IV. The changes in blood glucose following intravenous glucose were characteristic of diabetes mellitus, with marked hyperglycemia and a delayed fall. In direct contrast, the blood disappearance curve for fructose was, in every instance, essentially identical with that found in the normal group. Corresponding to these similar blood levels, the excretion of fruc-

TABLE II

Three hour excretion of hexose in urine after intravenous glucose and fructose in normals

\begin{tabular}{|c|c|c|c|c|c|c|c|c|c|}
\hline \multirow{2}{*}{ Subject } & \multirow{2}{*}{$\begin{array}{l}\text { Amount of } \\
\text { hexose } \\
\text { injected }\end{array}$} & \multicolumn{3}{|c|}{ After glucose } & \multicolumn{2}{|r|}{ • } & \multicolumn{2}{|c|}{ fter fructose } & \multirow[b]{2}{*}{ Fructose } \\
\hline & & Date & $\begin{array}{l}\text { Volume } \\
\text { of urine }\end{array}$ & Glucose & Date & $\begin{array}{l}\text { Volume } \\
\text { of urine }\end{array}$ & $\begin{array}{c}\text { Total } \\
\text { hexose }\end{array}$ & Glucose & \\
\hline J. 0. & $\begin{array}{l}g m . \\
61\end{array}$ & - & $m l$. & $\mathrm{gm}$. & $5 / 3 / 51$ & $\begin{array}{l}m l . \\
640\end{array}$ & $\begin{array}{l}g m . \\
3.1\end{array}$ & $\begin{array}{l}g m . \\
0.2\end{array}$ & $\begin{array}{l}g m . \\
2.9\end{array}$ \\
\hline J. C. & 67 & $\begin{array}{l}9 / 5 / 50 \\
5 / 18 / 51\end{array}$ & 1,250 & $\begin{array}{l}5.5 \\
3.4\end{array}$ & $5 / 7 / 51$ & 740 & 4.3 & 0 & $\begin{array}{l}4.3 \\
.,\end{array}$ \\
\hline W. D. & 80 & $9 / 28 / 50$ & 1,010 & 9.3 & $3 / 15 / 51$ & 946 & 5.9 & 0.1 & 5.8 \\
\hline
\end{tabular}


tose in the urine of the diabetic patient was in the of the fasting blood sugar and the delay in the same range (2.0 to $5.7 \mathrm{gm}$.) as in the normal. The diabetic subject differed from the normal in that, in all but one instance, there was a more marked rise in blood glucose following fructose. This rise was only roughly correlated with the severity of the diabetes as measured by the height return of the blood sugar to the fasting level after glucose. This blood glucose elevation caused an increased excretion of glucose, but in the three cases where excretion could properly be compared because of the approximate equality of the initial blood sugars (M. G., A. B., and

TABLE III

Comparison of effects of intravenous glucose and fructose in diabetes mellitus ( $1 \mathrm{gm}$. per $\mathrm{kg}$. as $10 \%$ solution in 60 minutes)

\begin{tabular}{|c|c|c|c|c|c|c|c|c|c|c|c|c|}
\hline \multirow[b]{2}{*}{ Subject } & \multicolumn{6}{|c|}{ Glucose } & \multicolumn{6}{|c|}{ Fructose } \\
\hline & Date & Time & $\begin{array}{c}\text { Blood } \\
\text { glucose }\end{array}$ & $\underset{\substack{\text { Blood } \\
\text { pyruvic } \\
\text { acid }}}{ }$ & $\begin{array}{l}\text { Plasma } \\
\text { citric } \\
\text { acid }\end{array}$ & $\begin{array}{c}\text { Serum } \\
\text { inorg. } \\
P\end{array}$ & Date & $\begin{array}{c}\text { Blood } \\
\text { fructose }\end{array}$ & $\underset{\substack{\text { pyrood } \\
\text { acidic }}}{\text { Blid }}$ & $\begin{array}{c}\text { Plasma } \\
\text { citric } \\
\text { acid }\end{array}$ & $\begin{array}{c}\text { Serum } \\
\text { inorg. } \\
P\end{array}$ & $\begin{array}{l}\text { Blood } \\
\text { glucose }\end{array}$ \\
\hline $\begin{array}{c}\text { M. G. } \\
\text { Age } \\
45 \\
\text { Wt. } \\
86 \mathrm{~kg} .\end{array}$ & $4 / 1 / 51$ & $\begin{array}{r}\min . \\
0 \\
30 \\
60 \\
90 \\
120 \\
180\end{array}$ & $\begin{array}{c}m g . \% \\
230 \\
533 \\
470 \\
428 \\
344\end{array}$ & $\begin{array}{c}\text { mg. \% } \\
1.57 \\
1.20 \\
1.07 \\
1.44 \\
1.74 \\
1.84\end{array}$ & $\begin{array}{c}\text { mg. \% } \\
2.77 \\
2.97 \\
2.94 \\
3.01 \\
3.31 \\
2.84\end{array}$ & $\begin{array}{c}\text { ms. \% } \\
3.78 \\
3.65 \\
3.87 \\
3.56 \\
3.78 \\
3.51\end{array}$ & $3 / 30 / 51$ & $\begin{array}{c}\text { mg. \% } \\
2 \\
89 \\
35 \\
19 \\
8\end{array}$ & $\begin{array}{c}\text { mg. \% } \\
1.63 \\
4.17 \\
4.01 \\
3.53 \\
2.14\end{array}$ & $\begin{array}{c}\text { mg. \% } \\
2.64 \\
\\
3.66 \\
3.57 \\
3.66 \\
3.51\end{array}$ & $\begin{array}{c}\text { mg. \% } \\
3.98 \\
3.34 \\
3.29 \\
3.92 \\
3.63 \\
3.42\end{array}$ & $\begin{array}{c}m_{8 .} \% \\
220 \\
259 \\
253 \\
254 \\
236\end{array}$ \\
\hline & & $\begin{array}{r}0 \\
30 \\
60 \\
90 \\
120 \\
180\end{array}$ & & & & r & $4 / 3 / 51$ & $\begin{array}{r}4 \\
78 \\
34 \\
16 \\
6\end{array}$ & $\begin{array}{l}1.66 \\
3.80 \\
3.56 \\
2.54 \\
2.06\end{array}$ & $\begin{array}{l}2.65 \\
3.10 \\
3.30 \\
3.18 \\
3.03\end{array}$ & $\begin{array}{l}4.00 \\
3.31 \\
3.39 \\
3.97 \\
3.48 \\
3.45\end{array}$ & $\begin{array}{l}177 \\
265 \\
258 \\
244 \\
228\end{array}$ \\
\hline $\begin{array}{c}\text { A. B. } \\
\text { Age } \\
53 \\
\text { Wt. } \\
55 \mathrm{~kg} .\end{array}$ & $4 / 14 / 51$ & $\begin{array}{r}0 \\
30 \\
60 \\
90 \\
120 \\
180\end{array}$ & $\begin{array}{l}236 \\
568 \\
443 \\
389 \\
297\end{array}$ & $\begin{array}{l}1.12 \\
1.23 \\
1.42 \\
1.55 \\
1.28\end{array}$ & $\begin{array}{l}2.38 \\
2.24 \\
2.36 \\
2.28 \\
1.90\end{array}$ & $\begin{array}{l}2.18 \\
2.10 \\
2.01 \\
2.12 \\
1.95 \\
1.95\end{array}$ & $4 / 12 / 51$ & $\begin{array}{r}4 \\
82 \\
30 \\
20 \\
8\end{array}$ & $\begin{array}{l}1.47 \\
4.12 \\
3.00 \\
2.49 \\
1.42\end{array}$ & $\begin{array}{l}2.68 \\
2.88 \\
2.76 \\
2.59 \\
2.00\end{array}$ & $\begin{array}{l}2.21 \\
1.41 \\
1.43 \\
1.78 \\
1.75 \\
1.86\end{array}$ & $\begin{array}{l}222 \\
243 \\
244 \\
228 \\
224\end{array}$ \\
\hline $\begin{array}{c}\text { M. H. } \\
\text { Age } \\
26 \\
\text { Wt. } \\
55 \text { kg. }\end{array}$ & $4 / 23 / 51$ & $\begin{array}{r}0 \\
30 \\
60 \\
90 \\
120 \\
180 \\
\\
0 \\
30 \\
60 \\
90 \\
120 \\
180\end{array}$ & $\begin{array}{l}368 \\
572 \\
640 \\
588 \\
586 \\
540\end{array}$ & $\begin{array}{l}0.80 \\
0.94 \\
1.02 \\
1.10 \\
1.10 \\
1.04\end{array}$ & & $\begin{array}{l}3.71 \\
3.74 \\
3.48 \\
3.43 \\
3.60 \\
3.40\end{array}$ & $\begin{array}{l}4 / 19 / 51 \\
4 / 24 / 51\end{array}$ & $\begin{array}{r}1 \\
57 \\
64 \\
22 \\
18 \\
5 \\
2 \\
2 \\
61 \\
61 \\
22 \\
11 \\
6\end{array}$ & $\begin{array}{l}1.34 \\
1.66 \\
1.95 \\
1.74 \\
1.68 \\
1.44 \\
1.36 \\
2.40 \\
2.24 \\
2.00 \\
1.74 \\
1.34\end{array}$ & $\begin{array}{l}2.02 \\
1.99 \\
2.02 \\
2.41 \\
1.93 \\
1.90 \\
\\
2.01 \\
2.01 \\
2.22 \\
2.04 \\
2.18 \\
1.98\end{array}$ & $\begin{array}{l}4.46 \\
3.26 \\
3.42 \\
4.18 \\
4.18 \\
4.28 \\
3.82 \\
3.20 \\
3.14 \\
3.68 \\
3.43 \\
3.63\end{array}$ & $\begin{array}{l}306 \\
408 \\
438 \\
508 \\
528 \\
525 \\
\\
400 \\
484 \\
531 \\
573 \\
570 \\
558\end{array}$ \\
\hline $\begin{array}{c}\text { J. R. } \\
\text { Age } \\
60 \\
\text { Wt. } \\
53 \mathrm{~kg} .\end{array}$ & $\begin{array}{l}4 / 25 / 51 \\
4 / 27 / 51\end{array}$ & $\begin{array}{r}0 \\
30 \\
60 \\
90 \\
120 \\
180 \\
\\
0 \\
90 \\
180\end{array}$ & $\begin{array}{l}226 \\
409 \\
462 \\
382 \\
346 \\
282 \\
\\
226 \\
374 \\
278\end{array}$ & $\begin{array}{l}0.83 \\
1.26 \\
1.26 \\
1.23 \\
1.23 \\
\\
1.20 \\
1.20 \\
1.42\end{array}$ & $\begin{array}{l}2.46 \\
2.51 \\
2.51 \\
2.30 \\
2.51 \\
2.49\end{array}$ & $\begin{array}{l}3.68 \\
2.92 \\
2.89 \\
3.20 \\
2.92 \\
2.86\end{array}$ & $4 / 26 / 51$ & $\begin{array}{l}4 \\
71 \\
70 \\
28 \\
19 \\
10\end{array}$ & $\begin{array}{l}1.31 \\
1.98 \\
1.90 \\
1.58 \\
1.60 \\
1.31\end{array}$ & $\begin{array}{l}2.38 \\
3.35 \\
2.76 \\
2.80 \\
2.76 \\
2.91\end{array}$ & $\begin{array}{l}2.78 \\
2.34 \\
2.29 \\
2.45 \\
2.55 \\
2.63\end{array}$ & $\begin{array}{l}224 \\
245 \\
293 \\
304 \\
279 \\
264\end{array}$ \\
\hline $\begin{array}{c}\text { E. R. } \\
\text { Age } \\
52 \\
\text { Wt. } \\
68 \mathrm{~kg} .\end{array}$ & $6 / 14 / 51$ & $\begin{array}{r}0 \\
60 \\
90 \\
120 \\
180\end{array}$ & $\begin{array}{l}162 \\
512 \\
415 \\
358 \\
256\end{array}$ & $\begin{array}{l}1.02 \\
1.23 \\
1.58 \\
1.39 \\
1.02\end{array}$ & $\begin{array}{l}2.58 \\
2.47 \\
2.72 \\
2.38 \\
2.08\end{array}$ & $\begin{array}{l}3.60 \\
3.24 \\
3.27 \\
2.88 \\
2.79\end{array}$ & $6 / 12 / 51$ & $\begin{array}{r}3 \\
90 \\
35 \\
16 \\
7\end{array}$ & $\begin{array}{l}1.02 \\
2.78 \\
2.36 \\
1.52 \\
1.36\end{array}$ & $\begin{array}{l}2.82 \\
3.26 \\
2.94 \\
2.30 \\
2.26\end{array}$ & $\begin{array}{l}3.46 \\
3.02 \\
3.34 \\
3.28 \\
3.14\end{array}$ & $\begin{array}{l}126 \\
185 \\
155 \\
131 \\
133\end{array}$ \\
\hline
\end{tabular}




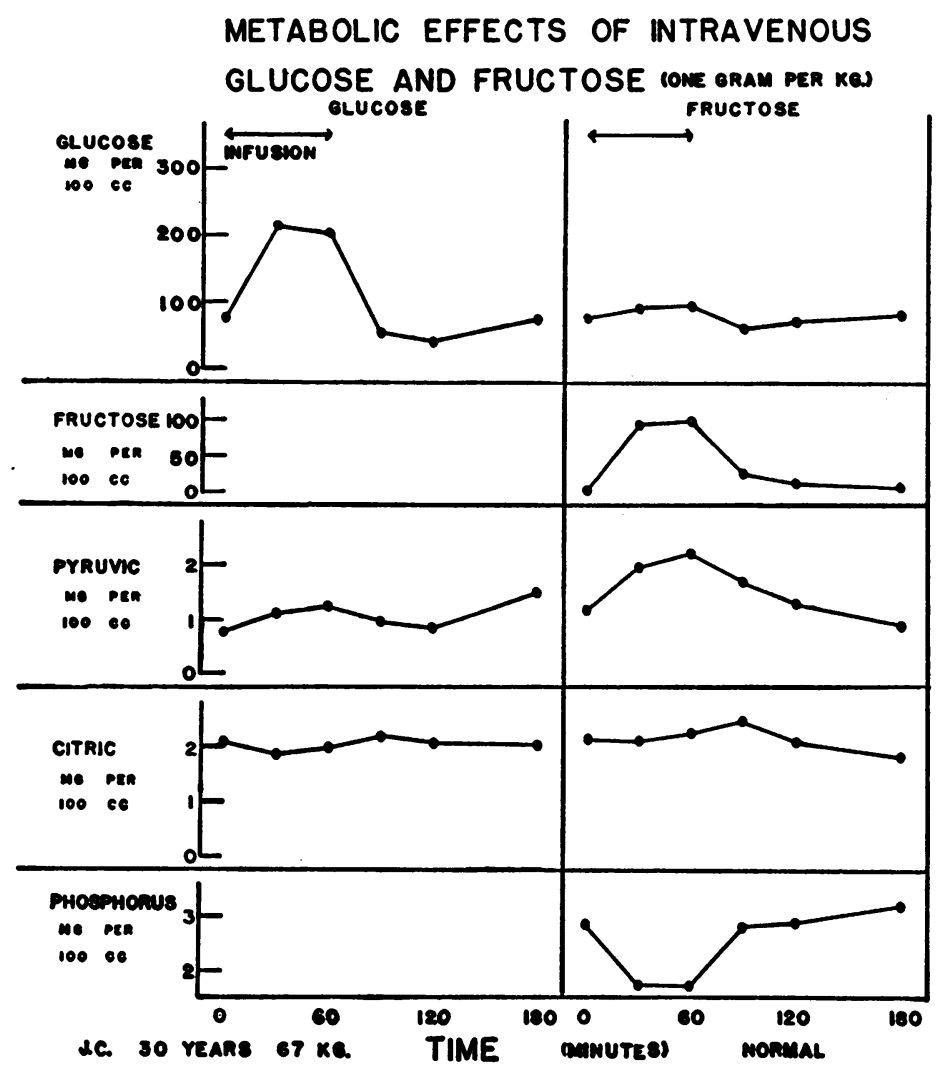

Fig. 1. Comparison of the Metabolic Effects of Intravenous Glucose and Fructose in a NORMAL Subject (J. C.)

TABLE IV

Three hour excretion of hexose in urine after intravenous glucose and fructose in diabetes mellitus

\begin{tabular}{|c|c|c|c|c|c|c|c|c|c|c|c|}
\hline \multirow{2}{*}{ Subject } & \multirow{2}{*}{$\begin{array}{l}\text { Amount } \\
\text { of hexose } \\
\text { injected }\end{array}$} & \multicolumn{4}{|c|}{ After glucose } & \multicolumn{6}{|c|}{ After fructose } \\
\hline & & Date & FBS* & $\begin{array}{l}\text { Volume } \\
\text { of urine }\end{array}$ & Glucose & Date & FBS* & $\begin{array}{l}\text { Volume } \\
\text { of urine }\end{array}$ & $\begin{array}{c}\text { Total } \\
\text { hexose }\end{array}$ & Glucose & Fructose \\
\hline M. G. & $\begin{array}{l}8 m . \\
80\end{array}$ & $4 / 1 / 51$ & $\begin{array}{c}\text { mg. \% } \\
230\end{array}$ & $\begin{array}{c}m l . \\
870\end{array}$ & $\begin{array}{c}g m . \\
26.1\end{array}$ & $\begin{array}{l}3 / 30 / 51 \\
4 / 3 / 51\end{array}$ & $\begin{array}{c}\text { mg. \% } \\
220 \\
177\end{array}$ & $\begin{array}{c}m l . \\
1,095 \\
767\end{array}$ & $\begin{array}{r}g m . \\
12.2 \\
9.8\end{array}$ & $\begin{array}{l}s m . \\
6.5 \\
4.4\end{array}$ & $\begin{array}{l}g m . \\
5.7 \\
5.4\end{array}$ \\
\hline A. B. & 55 & $4 / 14 / 51$ & 236 & 599 & 23.7 & $4 / 12 / 51$ & 222 & 787 & 9.7 & 5.9 & 3.8 \\
\hline M. H. & 55 & $4 / 23 / 51$ & 368 & 864 & 38.5 & $\begin{array}{l}4 / 19 / 51 \\
4 / 24 / 51\end{array}$ & $\begin{array}{l}306 \\
400\end{array}$ & $\begin{array}{l}830 \\
945\end{array}$ & $\begin{array}{l}23.7 \\
37.3\end{array}$ & $\begin{array}{l}21.7 \\
35.1\end{array}$ & $\begin{array}{l}2.0 \\
2.2\end{array}$ \\
\hline J. R. & 53 & $\begin{array}{l}4 / 25 / 51 \\
4 / 27 / 51\end{array}$ & $\begin{array}{l}226 \\
226\end{array}$ & $\begin{array}{l}596 \\
606\end{array}$ & $\begin{array}{l}29.7 \\
27.4\end{array}$ & $4 / 26 / 51$ & 224 & 570 & 19.7 & 16.5 & 3.2 \\
\hline E. $R$. & 68 & $6 / 14 / 51$ & 162 & 850 & 15.9 & $6 / 12 / 51$ & 126 & 868 & 3.8 & 0.1 & 3.7 \\
\hline
\end{tabular}

* Fasting blood sugar.

J. R.) $25 \%, 25 \%$, and $58 \%$ as much glucose was excreted after fructose as after glucose. When the urinary loss of fructose was added to that of glucose in the fructose experiments, the advantage was still apparent, with a saving of one-third to one-half of the total hexose. In the most severe diabetic subject (M. H.) a direct quantitative comparison could not be made because the fasting blood sugars were not in the same range. However, less glucose $(35.1 \mathrm{gm}$. as com- 


\section{METABOLIC EFFECTS OF INTRAVENOUS}

\section{GLUCOSE AND FRUCTOSE (ONE gRAM PER KQ.)}

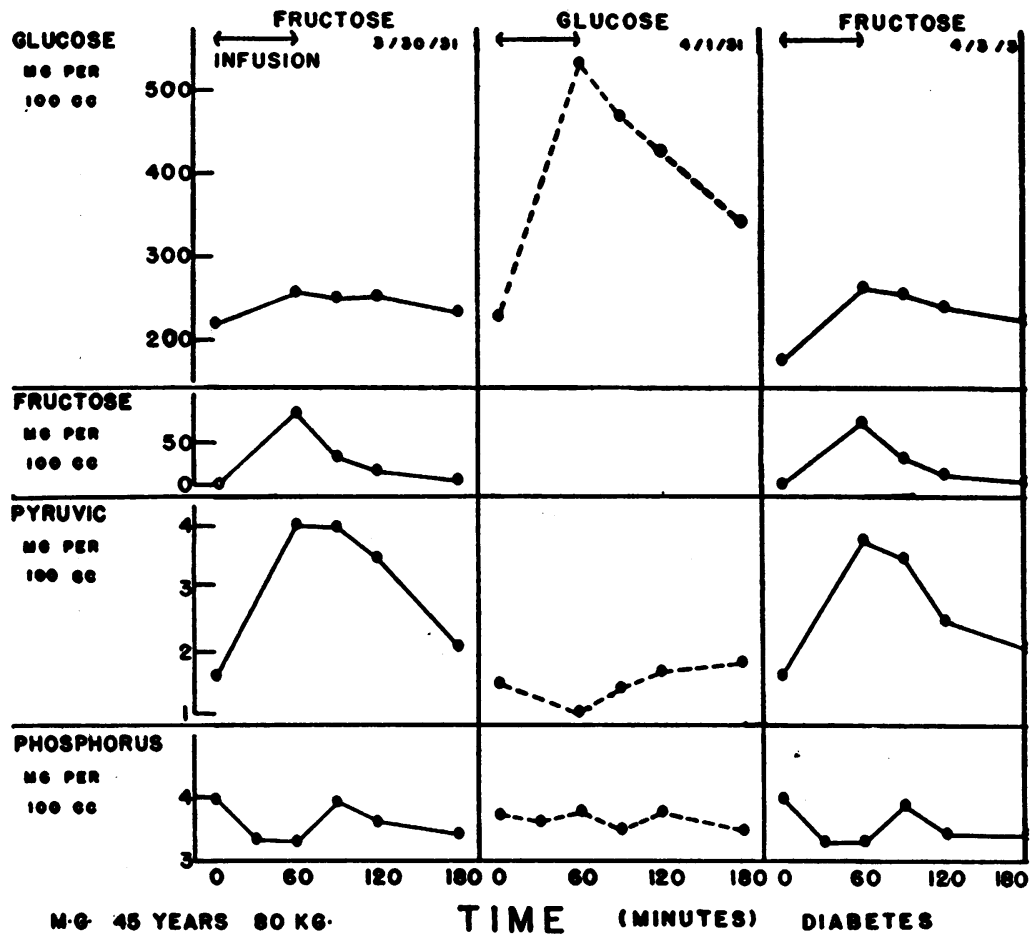

Fig. 2. Comparison of the Metabolic Effects of Intravenous Glucose and Fructose in a DIABETIC Subject (M. G.), Whose Diabetes Was of Recent Onset and Stable in Type

pared with $38.5 \mathrm{gm}$.) was lost after the fructose infusion when the initial blood sugar level was $400 \mathrm{mg}$. per $100 \mathrm{ml}$. than after the glucose injection when the initial blood sugar level was $32 \mathrm{mg}$. per $100 \mathrm{ml}$. less.

One of the striking differences in the metabolism of fructose and glucose in the diabetic subject was shown by the changes in blood pyruvic acid. After glucose, the rise in pyruvic acid was similar in magnitude to that observed in normal individuals; but it was delayed, and usually occurred during the period when the blood sugar was falling; in two instances a significant rise did not take place. ${ }^{6}$ After fructose, however, the rise occurred just as promptly as in the normal subject. In addition, the magnitude of the pyruvic

6 The changes in blood pyruvic acid in diabetic patients following the oral administration of glucose have been studied by several investigators. Bueding, Wortis and Fein (7) found either no increase in pyruvic acid or a rise (in four of 10 cases) which was smaller and had a tendency to occur later than in normal subjects. Klein (17) observed acid rise in the diabetic patient after fructose was as great as, or even greater than, the rise found in the normal subject. In four of the

a small and delayed rise. Horwitt, Hills and Kreisler (18) reported a rise which was of normal magnitude but appeared later. Root, Stotz and Carpenter (3) found that two of four clinically mild diabetic patients showed a pyruvic acid rise after glucose ingestion while only two of 20 cases with moderate or severe diabetes mellitus showed a significant rise which came only after one and one-half hours. Interpretation of the results of the last three studies is difficult since at least some of the subjects had received protamine zinc insulin within 14,20 or 12 hours, respectively, of the tests. Miller and his associates (19) administered $1 \mathrm{gm}$. of glucose per $\mathrm{kg}$. intravenously to three human subjects with diabetes and observed no significant rise in blood pyruvic acid. Bueding, Fazekas, Herrlich and Himwich (20) reported no increase in pyruvic acid in depancreatized dogs after the intravenous administration of $2.0 \mathrm{gm}$. of glucose per $\mathbf{k g}$. These results suggest that in the presence of a diminished insulin supply (as in some human diabetic patients) either a smaller than normal or a delayed rise in pyruvic acid may occur or both. In the complete absence of insulin 


\section{METABOLIC EFFECTS OF INTRAVENOUS}

\section{GLUCOSE AND FRUCTOSE (ONE GRAM PER KG.)}

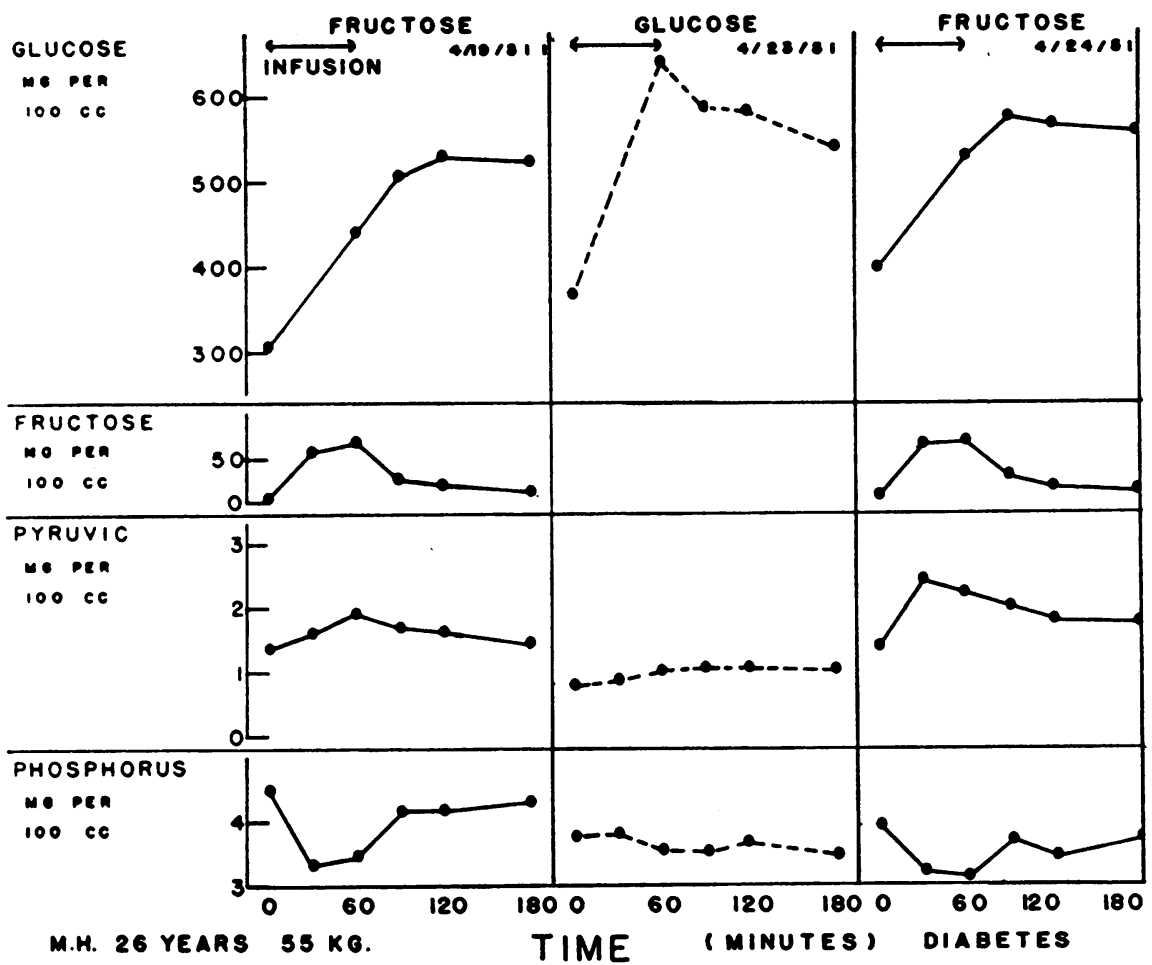

Fig. 3. Comparison of the Metabolic Effects of Intravenous Glucose and Fructose in a DIABETIC Subject (M. H.), Whose Diabetes Was of Long Duration and Was Labile in Type

cases (M. G., A. B., M. H., and E. R.) there was an inverse relationship between the rise in pyruvic acid and the rise in blood glucose after fructose administration. For example, in case A. B. a rise of $2.65 \mathrm{mg}$. per $100 \mathrm{ml}$. was associated with a rise of $22 \mathrm{mg}$. per $100 \mathrm{ml}$. in the blood glucose; whereas in case M. H. a rise of only $0.61 \mathrm{mg}$. per $100 \mathrm{ml}$. occurred when the blood glucose rose $222 \mathrm{mg}$. per $100 \mathrm{ml}$.

(as in the depancreatized $\mathrm{dog}$ ), on the other hand, no pyruvic rise at all was found after glucose administration. When, however, a large enough dose of glucose was given to the depancreatized dog to raise the blood level to between 700 and $1,000 \mathrm{mg}$. per $100 \mathrm{ml}$. a delayed rise in pyruvic acid occurred (20), indicating that the total dose and the rate of administration of glucose may also influence the entrance of glucose into the reactions of the Embden-Meyerhof scheme. Soskin and Levine (21) also found that the rate of utilization of glucose in the depancreatized, eviscerated dog was dependent upon the level of blood glucose.
Plasma citric acid levels were determined in four diabetic subjects after glucose administration. The changes in citric acid were variablein two cases there was a fall; in one, a rise; and in the fourth case there was no significant change. These results were similar to those reported by Pincus, Natelson, and Lugovoy (22). Following fructose administration, there was a significant rise in citric acid in five out of seven tests; these results approached those obtained after fructose in non-diabetic subjects.

It has long been established that in diabetes the decrease in serum inorganic phosphorus after the administration of glucose is diminished or abolished $(16,23)$. Insignificant falls of 0.27 , 0.23 , and $0.31 \mathrm{mg}$. per ml. were found in the first three cases, and again these occurred late; whereas after fructose in the same three cases the falls in phosphorus were 0.69 and 0.69 (M. G.), 0.80 (A. B.), and 1.20 and $0.68 \mathrm{mg}$. per $100 \mathrm{ml}$. 


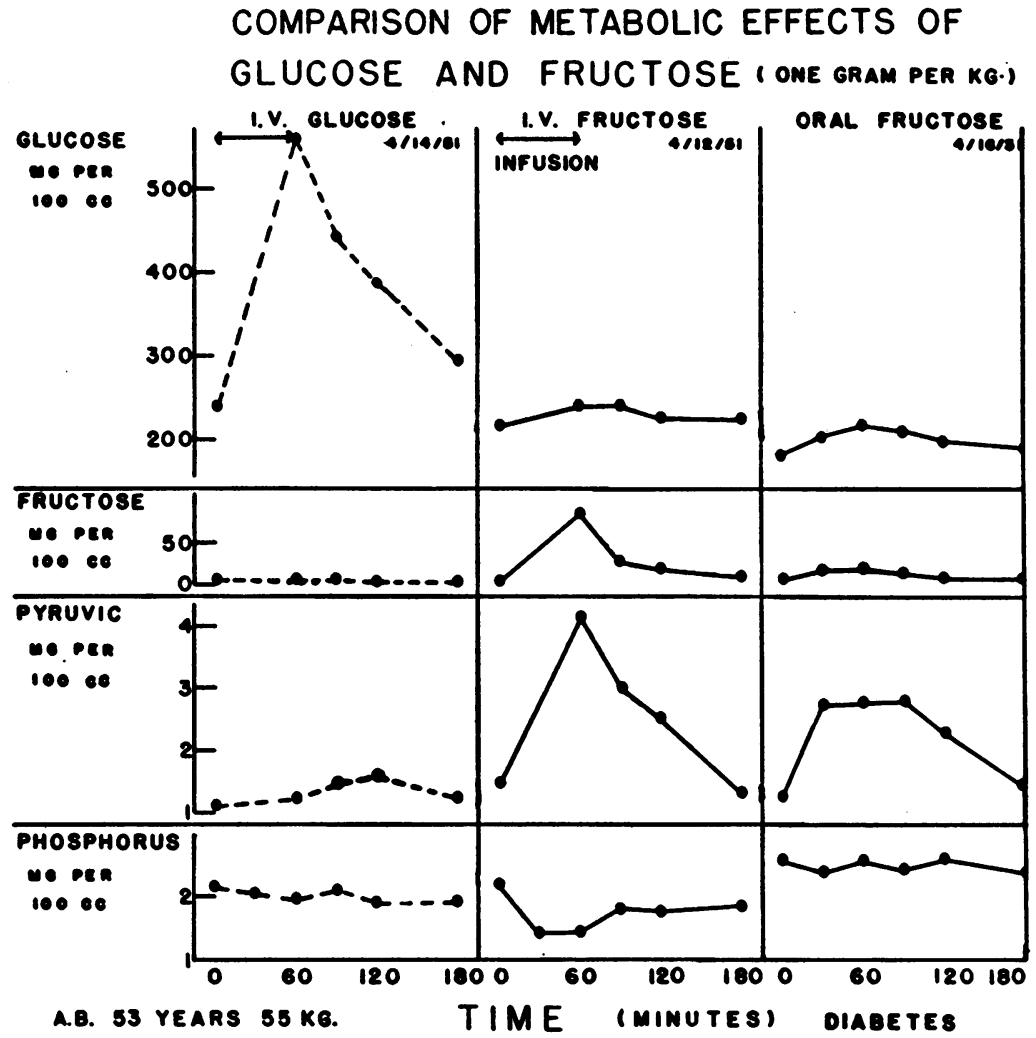

Fig. 4. Comparison of the Metabolic Effects of Intravenous Glucose ANd Fructose in a $D I A B E T I C$ Subject (A. B.)

The third column contrasts the effects of orally administered fructose.

(M. H.). In the fourth and fifth cases phosphorus fell after both glucose and fructose.

Figures 2 and 3 compare graphically the changes in blood glucose, pyruvic acid, and serum inorganic phosphorus in two different types of diabetes. The diabetes was of recent onset in case M. G. (Figure 2) who was of the older, obese type; while the diabetes had been present 12 years in case M. H. (Figure 3 ), representing the younger, more severe and labile group.

C. Oral fructose versus intravenous fructose in the diabetic subject. In one case (A. B.) an opportunity was available to compare the effects of fructose given by mouth with the same amount given intravenously ( $1 \mathrm{gm}$. per $\mathrm{kg}$.). The results are shown graphically in Figure 4. After oral administration, the highest blood fructose level was only $17 \mathrm{mg}$. per $100 \mathrm{ml}$., contrasted with a peak of $82 \mathrm{mg}$. per $100 \mathrm{ml}$. after the intravenous route was used, and even at 120 minutes the two blood levels were 8 and $20 \mathrm{mg}$. per $100 \mathrm{ml}$., respectively. Associated with the much lower blood level of fructose, the elevation of blood glucose was more than twice as great (51 mg. per $100 \mathrm{ml}$. as compared with 22) and remained higher for a longer period of time. Part of the fructose, therefore, must have been converted to glucose in its passage through the bowel wall and the liver. Despite a lower initial blood sugar in the oral experiment, there was an augmented excretion of glucose in the urine $(13.6 \mathrm{gm}$. as compared with $5.9 \mathrm{gm}$.) but only a minute amount of fructose. The rise in pyruvic acid after oral fructose was only three-fifths that found after the intravenous route was used, and no significant fall in inorganic phosphorus was found. It is evident from these findings that in diabetes fructose is metabolized in much greater quantities when given directly into the blood stream, because less of it is converted to glucose. 


\section{DISCUSSION}

The results of our studies indicate that 1 ) the metabolism of fructose differs from that of glucose in both the normal and diabetic subject, and 2) the metabolism of fructose in the person with diabetes is similar to that in the normal person, even in the absence of insulin.

The observation that, in normal individuals, the rise in the level of blood fructose following fructose administration is less than the rise in blood glucose after the injection of the same amount of glucose proves that fructose is removed from the blood more rapidly than glucose during the period of infusion. The rise in blood glucose following fructose administration indicates that part of the fructose is converted to glucose. Another fraction of the fructose is metabolized by way of the Embden-Meyerhof series of reactions and the tricarboxylic acid cycle. This is indicated by the rises in pyruvic and citric acid. Glycogen formation undoubtedly accounts for another part of the fructose removed from the blood (24). The fall in phosphorus after fructose reflects the process of phosphorylation which is involved in the metabolism of both hexoses studied.

Fructose produces a much greater rise in pyruvic acid than does glucose. Two possible explanations can be offered: 1 ) fructose enters the metabolic scheme closer to pyruvic acid, at a different point from glucose, 2) fructose enters at the same point as glucose (i.e., at glucose $6-\mathrm{PO}_{4}$ by way of fructose $\left.1-\mathrm{PO}_{4}[25]\right)$ at a more rapid rate, or is metabolized more quickly. The data obtained in these experiments do not permit us to choose between the two possibilities. That the elevation of pyruvic acid in diabetic subjects after fructose is not due to a decreased rate of removal, is indicated by the studies of Bueding and associates (20), which showed that there was no difference in the rate of disappearance of in.jected pyruvate from the blood in normal and depancreatized dogs. Oxidative metabolism of fructose seems to be unimpaired, according to the recent report of Chernick and Chaikoff (26). These workers found that the oxidation of $\mathrm{C}^{14}$-fructose to $\mathrm{CO}_{2}$ proceeded at normal rates in liver slices from alloxan diabetic rats. The greater rise in citric acid after fructose administration is still another indication of the difference between the metabolism of fructose and glucose.

Although the blood levels of fructose were lower than those of glucose, similar quantities of the two substances were excreted in the urines of the normal subjects. This observation can be explained by the fact that fructose appears in the urine at low blood levels, while glycosuria occurs only at higher levels of blood glucose.

The individual with diabetes mellitus handles fructose like a normal subject, as shown by the similar elevations of fructose, pyruvic acid, and (in several cases) citric acid; the falls in phosphorus and the total amount of fructose excreted in the urine are also comparable. The greater rise in blood glucose following fructose administration to the diabetic patient, as compared with the normal individual, probably reflects the diminished ability to utilize glucose, and possibly a greater conversion of fructose to glucose.

Fructose is better utilized by the diabetic when administered intravenously than when given orally, presumably because of its greater conversion to glucose in the intestine and liver when given by the latter route.

The difference in the metabolism of fructose and glucose in subjects with diabetes mellitus is much more marked than the difference in normal subjects. The diabetic individual appears to metabolize fructose at a normal rate, but glucose utilization is impaired. In these studies diminished glucose utilization is shown by the greater rise in glucose, delayed rise in pyruvic acid, diminished fall in phosphorus, and the increased excretion of glucose as compared to the changes found in the normal subjects.

That mechanisms exist to explain this difference in the metabolism of fructose and glucose is shown by the findings of Cori and Cori (27). In eviscerated rats insulin accelerated the disappearance of injected glucose, but not of injected fructose (27). This is now explained by the existence of separate "kinases" in liver and muscle for the disposal of fructose and glucose, respectively; apparently insulin acts only on the glucokinase of muscle (25, $28,29)$. A similar conclusion with respect to liver arises from the recent experiments of Chernick and Chaikoff (26).

The present observations on the utilization of 
glucose and fructose by normal and diabetic subjects are consistent with the theory that the phosphorylation of glucose to glucose-6-phosphate is impaired in diabetes, while the phosphorylation of fructose, which is under the influence of a separate hexokinase, at least in liver and muscle, and is uninfluenced by insulin, proceeds at a normal rate.

\section{SUMMARY AND CONCLUSIONS}

The demonstration by Cori that insulin influences the phosphorylation of glucose and that separate hexokinases for glucose and fructose exist in liver and muscle, raised the possibility that fructose might be better utilized than glucose in diabetic subjects. Accordingly, similar amounts of fructose and glucose were administered intravenously to five diabetic subjects. Three normal subjects were used for comparison.

In the normal subjects fructose produced a much greater rise in blood pyruvic acid, and a rise rather than a fall in plasma citric acid, as compared with glucose. The fructose disappeared more rapidly from the blood stream during the period of the infusion, since the blood level of fructose increased only half as much as the level of glucose. Similar amounts (less than 10\%) of fructose and glucose appeared in the urine.

In the diabetic subjects, in the absence of insulin, fructose produced the same rise in pyruvic acid as was found in the normal subjects, while glucose produced either a slight or delayed rise. Increases in plasma citric acid after fructose administration were similar to those in the normal individuals. The blood disappearance curve of fructose and the amount of fructose excreted in the urine in patients with diabetes were the same as in normal subjects. Fructose administration invariably produced a fall in serum inorganic phosphorus, while a fall did not usually occur after glucose. The increase in blood glucose after fructose injection was higher in diabetic subjects than in non-diabetic individuals. In one patient with diabetes oral administration of fructose, as compared with intravenous administration, produced a much lower level of blood fructose, a greater rise in blood glucose, a smaller rise in blood pyruvic acid, and a greater excretion of glucose.

These studies indicate that 1 ) the metabolism of fructose differs from that of glucose in both the normal and diabetic subject, and 2) the metabolism of fructose in the person with diabetes is similar to that in the normal person, even in the absence of insulin. The observations are consistent with the theory that the phosphorylation of glucose to glucose-6-phosphate is impaired in diabetes, while the phosphorylation of fructose, which is uninfluenced by insulin, proceeds at a normal rate.

\section{ACKNOWLEDGMENTS}

The authors wish to express their appreciation to Dr. Ernest Bueding and Dr. John P. Peters for their encouragement and guidance, and to Dr. Carl F. Cori for his constructive comments concerning the interpretation of the data.

\section{REFERENCES}

1. von Noorden, C., Die Zuckerkrankheit und ihre Behandlung. A. Hirschwald, Berlin, 1910, 5th edition.

2. Joslin, E. P., Root, H. F., White, P., and Marble, A., The Treatment of Diabetes Mellitus. Lea and Febiger, Philadelphia, 1946, 8th edition, p. 356.

3. Root, H. F., Stotz, E., and Carpenter, T. M., The respiratory quotient and blood pyruvate and lactate responses after oral ingestion of glucose and tructose in diabetes mellitus with and without insulin. Am. J. M. Sc., 1946, 211, 189.

4. Stewart, C. P., and Thompson, J. C., The conversion of laevulose and fatty acid into glucose. Biochem. J., 1941, 35, 245.

5. Bollman, J. L., and Mann, F. C., The physiology of the liver. XIX. The utilization of fructose following complete removal of the liver. Am. J. Physiol., 1931, 96, 683.

6. Weichselbaum, T. E., Elman, R., and Lund, R. H., Comparative utilization of fructose and glucose given intravenously. Proc. Soc. Exper. Biol. \& Med., 1950, 75, 816.

7. Bueding, E., Wortis, H., and Fein, H. D., Pyruvic acid metabolism in diabetes mellitus. Am. J. M. Sc., 1942, 204, 838.

8. Price, W. H., Cori, C. F., and Colowick, S. P., The effect of anterior pituitary extract and of insulin on the hexokinase reaction. J. Biol. Chem., 1945, $160,633$.

9. Somogyi, M., Determination of blood sugar. J. Biol. Chem., 1945, 160, 69.

10. Higashi, A., and Peters, L., A rapid colorimetric method for the determination of inulin in plasma and urine. J. Lab. \& Clin. Med., 1950, 35, 475.

11. Friedemann, T. E., and Haugen, G. E., Pyruvic acid. II. The determination of keto acids in blood and urine. J. Biol. Chem., 1943, 147, 415.

12. Natelșon, S., Pincus, J. B., and Lugovoy,. J. K., Microestimation of citric acid; a new colorimetric reaction for pentabromoacetone. J. Biol. Chem.. 1948, 175, 745 . 
13. Taussky, H. H., and Shorr, E., A microcolorimetric method for the determination of citric acid. J. Biol. Chem., 1947, 169, 103.

14. Fiske, C. H., and Subbarow, Y., The colorimetric determination of phosphorus. J. Biol. Chem., 1925, 66, 375.

15. Taft, H. P., Miller, M., Drucker, W. R., and Craig, J. W., Metabolic and endocrine changes with hypoglycemia. J. Clin. Endocrinol., 1951, 11, 752.

16. Forsham, P. H., and Thorn, G. W., Changes in inorganic serum phosphorus during the intravenous glucose tolerance test as an adjunct to the diagnosis of early diabetes mellitus. Proc. Am. Diabetes Assoc., 1949, 9, 99.

17. Klein, D., The effects of administration of glucose and insulin on blood pyruvate and lactate in diabetes mellitus. J. Biol. Chem., 1942, 145, 35.

18. Horwitt, M. K., Hills, O. W., and Kreisler, O., Lactic and pyruvic acids in the blood after glucose and exercise in diabetes mellitus. Am. J. Physiol., 1949, 156, 92.

19. Miller, M., Bueding, E., Strauch, R. O., Owens, J., and Woodward, H., Studies on pyruvate and citrate metabolism in man and animal. Proc. Am. Diabetes Assoc., 1949, 9, 83.

20. Bueding, E., Fazekas, J. F., Herrlich, H., and Himwich, H. E., Effect of insulin on pyruvic acid formation in depancreatized dogs. J. Biol. Chem., 1943, 148, 97.

21. Soskin, S., and Levine, R., A relationship between the blood sugar level and the rate of sugar utilization, affecting the theories of diabetes. Am. J. Physiol., 1937, 120, 761.

22. Pincus, J. B., Natelson, S., and Lugovoy, J. K., Response of citric acid levels to oral administration of glucose. II. Abnormalities observed in the diabetic and convulsive state. J. Clin. Invest., 1948, 27, 450.

23. Bolliger, A., and Hartman, F. W., Observations on blood phosphates as related to carbohydrate metabolism. J. Biol. Chem., 1925, 64, 91.

24. Cori, C. F., The fate of sugar in the animal body. III. The rate of glycogen formation in the liver of normal and insulinized rats during the absorption of glucose, fructose and galactose. J. Biol. Chem., 1926, 70, 577.

25. Cori, G. T., Ochoa, S., Slein, M. W., and Cori, C. F., The metabolism of fructose in liver. Isolation of fructose-1-phosphate and inorganic pyrophosphate. Biochim. \& Biophys. Acta, 1951, 7, 304.

26. Chernick, S. S., and Chaikoff, I. L., Two blocks in carbohydrate utilization in the liver of the diabetic rat. J. Biol. Chem., 1951, 188, 389.

27. Cori, C. F., and Cori, G. T., Fate of glucose and other sugars in the eviscerated animal. Proc. Soc. Exper. Biol. \& Med., 1928_29, 26, 432.

28. Slein, M. W., Cori, G. T., and Cori, C. F., A comparative study of hexokinase from yeast and animal tissues. J. Biol. Chem., 1950, 186, 763.

29. Cori, C. F., Personal communication.

\section{APPENDIX I}

TABLE $v$

Clinical data on diabetic subjects

\begin{tabular}{|c|c|c|c|c|c|c|}
\hline Subject & $\begin{array}{c}\text { Hospital } \\
\text { no. }\end{array}$ & Age & Sex & $\begin{array}{l}\text { Duration of } \\
\text { diabetes }\end{array}$ & $\begin{array}{c}\text { Insulin } \\
\text { dose }\end{array}$ & Other data \\
\hline $\begin{array}{l}\text { M. G. } \\
\text { A. B. } \\
\text { M. H. } \\
\text { J. R. } \\
\text { E. R. }\end{array}$ & $\begin{array}{l}607-250 \\
608-037 \\
201-785 \\
102-976 \\
619-071\end{array}$ & $\begin{array}{l}45 \\
53 \\
26 \\
59 \\
\\
53\end{array}$ & $\begin{array}{l}\mathbf{F} \\
\mathbf{F} \\
\mathbf{M} \\
\mathbf{F}\end{array}$ & $\begin{array}{l}5 \text { wks. } \\
1 \text { yr. } \\
12 \text { yrs. } \\
7 \text { yrs. } \\
2 \text { yrs. }\end{array}$ & $\begin{array}{c}\text { (units per day) } \\
40 \\
65 \\
50 \\
30 \\
25\end{array}$ & $\begin{array}{l}\text { Obesity, hypertension } \\
\text { None } \\
\text { Intermittent hypertension, neuropathy } \\
\text { Diabetes developed after partial pancre- } \\
\text { atectomy for islet cell adenoma, } 1944 \\
\text { Mild hypertension, retinal exudates }\end{array}$ \\
\hline
\end{tabular}

\section{APPENDIX II}

After the completion of this manuscript the paper of A. Pletscher, H. Fahrländer, and H. Staub, Helvet. Physiol. et Pharmacol. Acta, 1951, 9, 46, came to our attention. Fructose and glucose $(0.5 \mathrm{gm}$. per $\mathrm{kg}$. per 20 min.) were administered intravenously to normal and di- abetic subjects. Their findings with regard to the similarity of the blood fructose disappearance curve and the rise in blood pyruvic acid after fructose injection were similar to those reported here. Plasma citric acid and hexose excretion were not determined. 